encouragement of new contacts between different branches of science. An efficient world Organisation would have unequalled opportunities for bringing together fertile new personalities and ideas, lying outside the old classifications and organizations. The most obvious ground for development is in the region between the natural and the social sciences.

While new subjects should be stimulated and fertilized, similar attention should be paid to now places. Modern means of transport and communication have brought eities hitherto quite isolated from the cultural current of the world within a few hours' journey of the main centres. A few years ago, the acceptance of a scientific post in an institute in a distant country usually meant cultural exile. With a world Organisation to assist in communications, such an outpost may offer more interesting opportunities to the research worker than he may find in the more crowded and conventional places at home.

A world Organisation for educational, scientific and cultural co-operation, conducted with a positive constructive spirit, ean perform great and necessary services in the extension of existing international scientific co-operation, and the creation of new activities to meet the needs of the times.

\section{A PERMANENT INTERNATIONAL SCIENTIFIC COMMISSION}

\section{By Prof. J. D. BERNAL, F.R.S. Birkbeck College}

$I^{\mathrm{T}}$

$\mathrm{T}$ is sincerely to be hoped that the United Nations Conference for the Establishment of an Educational and Cultural Organisation will, as one result of its deliberations, set up some form of international scientific commission. Such a body has long been needed and never more than in the present period of rehabilitation and reconstruction. The experiences of the War have shown, not only in industrial countries but also in the agricultural and other undeveloped regions, that the rational application of scientific knowledge and the initiation and carrying out of research and development in relation to current problems is an absolute necessity for progress. The War has also shown that the gap which has long existed between scientific research and practical results can, with suitable organization, be drastically narrowed. This experience bears with it the responsibility for seeing that methods at least as efficient shall be put into operation with the minimum of delay for the purposes of peace.

One of the main lessons of war science was its transcendence of national boundaries. In most fields of science there was a complete pooling of British Commonwealth and United States of America scientific resources. In some fields of science, notably medical, the pooling also included, within limits of difficulties of communication, the Soviet Union and China. But the actual geographical extent of scientific collaboration was still wider; it ranged over the whole of the fields of operation of allied armies and supply services, that is, over practically all but enemy-occupied territory. The work was planned and co-ordinated in regard to problems and needs rather than to individual and national contributions. The British Commonwealth Scientific Office in Washington was a focus of common scientific planning and information such as has never existed in the world before and one well justified by its results. There could be correlated, for example, work on insecticides such as D.D.T. being applied all the way from New Guinea to West Africa, and this was not the only centre. Men of science attached to the Middle East Supply Centre at Cairo were examining all the related problems of the region---of agriculture, industry and health-from Moroce to Baluchistan. The advantages to be got from seientific collaboration on a regional basis are now proved; but to safeguard them requires a permanent form of organization which only the United Nations can provide.

Another lesson of equal importance was that the distinction between the different sciences tended to disappear in practice in this type of organization. In fact one of the main lessons of the War was that mixed research teams, ranging from mathematicians and physicists to economists and psychologists, were needed to cope with regional problems in their entirety. Even in highly industrialized countries we are beginning to find out that the physical scientists and the technicians cannot get to work effectively unless they can see their problems in a framework which only social scientists ean grasp and which only statisticians can convert into figures on which quantitative action can be taken. This was effectively what was done in the building up of "operationa] research" during the War, and already the techniques of operational research are being applied to the building and export industries in Britain. The need for them on an international scale will be far greater.

The world of science after the War is ripe for great changes. In the United States and Great Britain science has been relatively undamaged and much increased in scope and effective organization. In the Soviet Union, in spite of the almost total devastation of the western areas, science has not only been maintained but has grown. By contrast, in the majority of the occupied countries, science has barely survived destruction and persecution, while both there and in the countries of Asia and Africa there is an increasingly conscious demand for more science. The devastated countries noed immediate help, but it will not be sufficient, or, indeed, desirable, simply to return to pre-war conditions. The smaller countries already feel the need for larger units of scientific intercommunication. In a sense, German science provided this before the War, and the filling of the vacuum left by the perversion and destruction of German science is a task which can only be carried out by organized international action. It should be possible to get away from the conception which had grown up before the War, of scientific circles confined to a large extent by the eirculation of journals in the same language, towards one of a world scientific commonwealth. This implies, however, a serious effort to recast the whole system of scientific publication and personal communication.

Such a task is eminently one for the new United Nations Organisation. What is a reconstitution of science in some of the European countries is, for many of the backward countries of the world, a first creation of science. The history of the Soviet Republies of Central Asia shows how rapidly science can be built up and how eagerly it is seized on by a population starting from a medieval standard of culture. During the war years we have seen another example in the extraordinary effort to expand and apply science which has been carried out under the most adverse conditions in China. The part that Dr. Joseph Needham's Sino-British Mission has taken in 
this effort is an extremely good example of both the needs and opportunities for international collaboration. As a result of this experience, Dr. Needham is convinced that similar international collaboration would be just as much needed and appreciated in all relatively undeveloped countries.

The men of science of this and most other industrial countries have been oceupied in the last six years largely with the important tasks of war, and have engaged in international collaboration for that purpose. In this they have learned both of the unity of the natural and social sciences and that of all peoples of the world. The problems of peace can start from this experience, but there is no question of applying it in a mechanical way. Much research and discussion must take place before a complete and effective system of united world scientific collaboration can be built up. This is now of particular importance in the light of the Soviet Government's expressed view that the full organization of cultural and scientific activities should await the setting up of the United Nations Economic and Social Council. It is to be hoped that in a few months time this will have occurred and that both the natural and social sciences will find their place in an all-inclusive international organization.

\section{THE PLACE OF SCIENCE AND INTERNATIONAL SCIENTIFIC CO-OPERATION IN POST-WAR WORLD ORGANIZATION}

\author{
BY DR. JOSEPH NEEDHAM, F.R.S.
}

$M$ $Y$ experience during the past two years in China in organizing and directing scientific and teohnical co-operation between China and the United Kingdom has led me to devote much thought to post-war international scientific co-operation. The present memorandum, sketched out in Chicago and Washington in March 1945 and completed in Chungking in May 1945, does not necessarily represent the views of any qrganization, but are my own views.

In the past, in times of peace, men of science themselves organized periodical international congresses for each science; and for certain branches of science (though not for all) there were successful international unions, or permanent bureaux, able to deal with day-to-day co-operation. These unions were federalized in an International Council of Scientific Unions, which, however, was not as successful as it might have been, due to the lack of an adequate secretariat. The International Council was associated with the League's International Institute of Intellectual Cooperation, but this itself was imperfect.

In war-time all these international agencies have gone into a state of suspended animation. Under the exigencies of war, the United Nations set up in each others' capitals science co-operation offices to deal with the emergency exchange of scientific and technical information bearing on military affairs. Most of these offices, such as the British Commonwealth Scientific Office in Washington; the United States Scientific Mission in London (under the Office of Scientific Research and Development); the French Scientific Missions in London and Montreal, in general much more efficiently run than anything known to international science in peace-time, deal to the extent of some 85 per cent with war science But in one case (the British Scientific Office in Chung king) a condition more similar to what might pertain in peace-time is found. These science co-operation offices differ from pre-war international scientific co-operation mainly in that they have adequate funds, secretariat and mechanical aids; and are not confined to any one science, but have to promote general scientific co-operation between the countries which they link. They are, therefore, rather a new departure; and point the way for the future.

The pre-war international scientific unions were thus limited as to subject-matter; the bilateral science co-operation offices are limited as to national scope. What we need to-day is fundamentally an attempt to combine the methods which science has spontaneously worked out for itself in terms of peace, with those which the nations have had to work out under the stress of war. None of the machinery ought to be scrapped. The problem is to weld it into a satisfactory functioning system.

In the future, there are two other types of international scientific intercourse which may grow up. One is the further extension into the scientific field of the bilateral cultural goodwill organizations (such as the British Council, Cultural Division of the State Department, etc.). The other is the appointment of scientific attachés in the principal embassies, a measure which the continuing interchange of information on war science will almost certainly necessitate. While there is much to be said for both these methods, I feel that these methods are not fitted to play the major part, though they may well play a valuable minor part, in the international exchange of so basically international an activity as science. Now is the time to attempt the establishment of an International Science Co-operation Service in which a supra-national loyalty would be possible, as it was in the case of the most successful League agencies.

In general, it may be said that there is a universal desire among men of science to see better international scientific contacts after the War. The dependence of all modern world civilization on applied science must find its expression in the sphere of international relations. This desire is more strongly expressed, however, the further one goes away from the great scientific and industrial centres of Europe and the United States. The picture of world science looks very different when seen from Rumania, Peru, Java, Siam or China.

It is often thought that in science everyone knows everyone else, and can, therefore, easily get in touch when any problem arises which calls for it. But this is not the case in the greater part of the world. A Venezuelan economic entomologist may have a problem very similar to that of a Chinese economic entomologist; but the difficulties of their coming into touch are enormous. A Rumanian organic chemist may need a few grams of a substance only being produced in India or Canada; but if he only knows his own language it will not be so easy to get it. The Australian workers on alunite needed for years the publications of the Chinese National Academy on the same subject; but were never able to get them until an exchange was arranged through the British Scientific Office in Chungking.

Allied to what may be called this "periphery principle' of concentrating the help of an International Science Co-operation Service where it is most needed, that is, to the scientific men isolated around the periphery of the 'bright zone', is the 